\title{
LINNAEUS AS AN INTERMEDIARY BETWEEN ANCIEN'T AND MODERN ZOÖLOGY; HIS VIEWS ON THE CLASS MAMMALIA.
}

By W. K. Gregory, M. A.

In connection with the two hundredth anniversary of the birth of Card von Linne, or Carolus Linnseus, it may not be inappropriate to consider him in his capacity of bridging over the gap between ancient and medieval zoölogy on the one hand and modern zoölogy on the other, and further to glance at the principles and facts upon which he based his two great contributions to the broader knowledge of the class of which man is the dominating member. For this purpose the history of zoölogy may be divided, in a general way, into seven epochs: the Aristotelian, the Scholastic, the Renaissance, the Raian, the Linnæan, the Cuvierian, and the Darwinian. There are also two axioms which it will be well to bear in mind. 'The first is, that Linneus became a point of departure in the history of modern biology, only because he was in turn the product of the intersection of many important historical series which ramify and intertwine indefnitely, and stretch back into the remote past of every aspect of life. The second axiom is, that every new idea, or, for that matter, every new event, is the fertile hybrid resulting from the fortuitous crossing of several specifically distinet old ideas or events.

\section{Tye Aristotelian Epoch.}

The first epoch under consideration is that of $A$ ristotle, of the fourth century B.C., and it may be characterized as the initial analytical epoch. Aristotle's theory of the genetic relationship of the chain of beings from polyp to man did not, of course, materially influence Jinneus. The idea of evolution was not destined to come to its fruition through Aristotle, the schoolmen, or even in Linnseus or Cuvier. The true relation of Aristotle as a sustematic zoölogist to Ray and Limnarus is exhibited in the following woll-known citations from " The Parts of Animals."

"Some animals are viviparous, some ovipurous, some vermiparous. The viviparous are such a.s man and the borse, and all those animals which have bair; and of the aquatic anirmals, the whale kind as the dolphin and cartilaginous fisbea (in mference to the viviparity of rertain sharks) (Book [, Chap. V). Of quadrupeds which have blood and are viviparous, some are (as to their extremities) many-rloven, as the hands and fert of man. For some are many-toed, as the lion, the dog, the panther; some are bifid. and hawe hoofs instead of nails, as the sheep. the goat the elephant 
the hippopotamus; and some have undivided feet, as the solid-hoofed animals, the horse and ass. The swine kind share both characters [an allusion to the 'mule footed' swine, monstrosities in which the median digits are fused, and terminate in a solid composite hoof]" (Book II, Chap. V).

Ray and later writers probably had this passage in mind when they used the descriptive terms "multifido," "bifido," "solidungula," "ungulata," "unguiculata," fissipedes." Here, also, attention is directed to the feet as exhibiting characteristic differences. In another passage Aristotle says,-

"Animals have also great difierences in the teeth both when compared with each other and with man. For all quadrupeds which have blood and are viviparous have teeth. And in the first place some are ambidental ${ }^{1}$ (having teeth in both jaws): and some are not so, wanting the front teeth in the upper jaw. Some have neither front teeth nor horns, as the camel; some have tusks, ${ }^{2}$ as the boar; some have not. Some have serrated teeth, ${ }^{3}$ as the lion, the panther, the dog; some have the teeth unvaried, as the horse and the ox; for the animals which vary their cutting teeth have all serrated teeth. No animal has both tusks and horns; nor has any animal with serrated teeth either of those weapons. The greater part have the front teeth cutting, and those within broad" (Book I, Chap. II).

This passage evidently directed the attention of later writers to the importance of the teeth as a means of distinguishing and hence of classifying mammals, and we shall see that Ray and, later, Linnæus were quick to a vail themselves of the suggestion.

Aristotle was quite unconscious of the classification that has been ascribed to him, as Whewell ${ }^{\mathbf{5}}$ shows; but "Aristotle does show, as far as could be done at his time, a perception of the need of groups and of names of groups in the study of the animal kingdom, and thus may justly be held up as the great figure in the prelude to the formation of systems which took place in more advanced scientific times." Whewell also quotes passages that show Aristotle's recognition of the lack of generic names to denominate natural groups. Aristotle says that "of the class of viviparous quadrupeds there are many genera, ${ }^{6}$ but these again are without names, except specific names, such as man, lion, stag, horse, dog and the like. Yet there is a genus of animals that have manes, as the horse, the ass, the oreus, the ginnus, the innus and the animal which in Syria is called heminus (mule)... Wherefore," he adds (that is, because we do not possess genera and generic names of this kind), "we must take the species separately and study the nature of each." "These passages," Whewell continues, "afford us sufficient ground

Apфósovta.

- Avertál hasta.

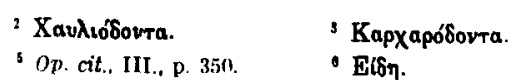


for placing Aristolle at the head of those naturalists to whom the first vicws of the necessity of a zoological system are due" (Op. cit., p. 352).

\section{Tye Scholastic Epoch}

From the time of Aristotle and his classical successors until the rise of scholasticism in the eleventh century, Europe, as every one knows, was too much preoccupied with world-wide displacements and readjustments of peoples and of institutions to pay particular attention to natural science; and even the Scholastic Epoch in the history of philosophy and science was chiefly occupied with the further development and systematization of the great body of religious and metaphysical doctrines. So far as natural history is concerned, it is perhaps rather a further interregnum than an epoch, rather an era or lapse of uneventful time than a time of the slow ascension of some great illuminative idea. The anthropocentric idea dominated in natural history as the greocentric idea dominated in astronomy; hence a knowledge of the real or supposed propertics of animals and particularly of plants was chiefly cultivated in connection with alchemy, magic and materia medica. The medieval imagination, full of mysticism, eager for the uncanny and fantastic and teeming with images of ubiquitous devils, flourished on the marvelous tales of a "Sir John Maundeville," and peopled the earth with the monsters which so long survived and ramped in the Terre Incognitx of world maps. In the schools, citations from authorities were accepted in lieu of proof, and the simple zoölogy of Aristotle and the scriptures was deeply covered by the aceretions of learned exegesis.

Scholasticism reached its prime as carly as the thirteenth century, in the system of the illustrious St. Thomas Aquinas, the "princeps scholasticorum." Afterward, while the renaissance movernent was discovering new worlds in all directions, scholasticism in general (but with some brilliant exceptions) rapidly reached the "phylogerontic stage" of its evolution, and produced all sorts of bizarre specializations in terminology and in dialectics.

It has been said of the scholastic philosophy that it "vigorously exercised the understanding without bringing it to any conclusions." IIonever this may be, it cannot be doubted that the very excesses of scholasticism stimulated the reactive return to experience, which gave rise incidentally to biological science. The schoolmen furthermore perpetuated and aroused interest in Aristolle's analyses, and rave currency to many methods of analysis and description. Among these we may cite, first, the dichotomous method of division, which is a forerunner of modem classifications; second. the logical concepts of genus and speries. Especially notewortlyy was the expansion of classical Latin into a highly specialized language of philosophy and srience 


\section{The Renaissance Epoch.}

Biological science, and especially zoölogy, did not respond fully to the impulse of the Renaissance movement until literature, politics, astronomy and geographical discovery had made the most signal advances. Hence in Aldrovandi (1522-1605) and Gesner (1516-65) the superstitions and myths of the middle ages still linger, while the systematic work of future generations is initiated in the extensive illustrated catalogues and descriptions of plants and animals. On the philosophical side of zoölogy, the Englishman Wotton, in his "De Differentiis Animalium" (Paris, 1552), "rejected the legendary and fantastic accretions [of medieval zoölogy] and returned to Aristotle and the observation of nature" (Lankester ${ }^{1}$ ). One of the contemporaries of Gesner and Wotton was the founder of anatomy, Andreas Vesalius (1514-64), who boldly broke with tradition, and declared that the source of knowledge of the human body should be, not Galen, but the human body itself.

Near the end of this period, the botanist, Cesalpino (Casalpinus) of Arezzo (1519-1778), a celebrated scholastic philosopher, published his voluminous work "De Plantis" (1583). In this work, which was inspired by the new idea of direct observation, the confused arrangements of plants of the earlier herbalists were replaced by an orderly classification suggested by the brigades of an army, and founded upon the number, the position and the figure of the reproductive parts. He divided plants into ten great classes, which were again subdivided; to these assemblages he gave monomial names in substantive form. Linnæus himself says of him, that, "though the first in attempting to form natural orders, he observed as many as the most successful later writers" (Whewell, Op. cit., pp. 282, 283).

A reason for this precocious development of a natural classification of plants may be sought in the very multiplicity of kinds and the large herbaria and horticultural gardens in existence, which necessitated some sort of orderly arrangement and which would assist the eager student to recognizc related series. We note in contrast the delayed progress of the classification of the mammals due to the comparative fewness of known forms, the greater complexity of organization and the difficulties of observation.

\section{The Raian Epoch, the Dawn of Modern Zoölogy. .}

Among those who contributed the data for Linnæeus's generalizations, no name is more important, at least in the history of vertebrate zoölogy, than

I E. Rry Lankester. The History and Scope of Zoology, in The Advancement of Science Iondon, $1890, \mathrm{p}, 293$ 
that of John Ray. Accordingly, the fourth epoch under consideration may be termed the Raian Epoch, and culminates with the publication in 1693 of Ray's "Synopsis Methodica Animalium Quadrupedum et Serpentini Generis," which is one of the great landmarks in the bistory of classification. Ray's debt to the past is shown in the facts that his lucid tabular analyses of the common structural features of animals are arranged dichotomously; that in each division and subdivision a single adjective or adjectival phrase indicates the most important common feature of the animals in question, and that these terms are, as we have seen, in many cases borrowed from Aristotle.

Ray, like Linneus, gave more attention to plants than to animals, and depended upon his colleaguc, Willughby, for much of the data, especially in the fishes. Like Linnæus also, Ray had a superb gift of order and a philosophical mind that made him a worthy countryman and contemporary of Sir Isaac Newton.

In his tabular analysis, Ray distinctly foreshadows Linnaus in the following points:-

1. The higher vertebrates are contrasted with the fishes as breathing by lungs instead of gills.

2. The whales are chassed with the viviparous animals and expressly removed from the fishes, from which they were further distinguished by the horizontality of the tail-fin. This step, however, was felt to be so radical that Ray afterwards constructed a definition which included both whales and fishes.

3. As remarked by Gill, the terrestrial or quadruped mammals are bracketed with the aquatic as "Vivipara," and contrasted with the "()vipara" or "Aves." "The Vivipara are exactly co-extensive with Mammalia, but the word "vivipara' was used as an adjective and not as a noun." I This distinction seems to have been an important one, when substance was so carefully distinguished from attrilute. Ray cmphasized the common attributes of all the terrestrial hairy quadrupeds, of the amphibious hairy animals such as the seals and manati, and of the purely aquatic and fish-like Cetaceans; but he does not seem to have insisted that all these animals agreed in essence and substance as well as in attribute, so that they should require a new substantive name such as linnames afterward applied to them.

4. The double ventricle is noted as characteristic of both Vivipara and Ovipara.

5. In order to associate the "manati" and other amphibious mammals with their terrestrial congeners, the term "hairy animals" is employed as more comprehensive than quadrupeds.

1 The Story of a Word Mammial, in Foprtar Science Ifonthly. Vol. IXI Septemter, 1902. pp. 494-438. 
Ray further set the standard for Linnæus in his concise descriptions of European and foreign mammals, especially those described by travelexs in America and in the East. Ray often used the term "species" merely as the equivalent of the middle English "spece," which survives in our word spice," and meant "kind:" it was also equivalent to the logical "species" (cf. the Greek $\epsilon i \delta o s$ ) of the schoolmen, and is exemplified in Ray and Willughby's "Historia Piscium" in such phrases as "clarias niloticus Belonii mustelæ fluviatilis species," "bagre piscis barbati ac aculeati species." But Ray also used the term "species" in quite a Linnæan manner, as in the names Ovis laticauda, Ovis strepsiceros and Ovis domestica. In form, at least, this foreshadows the binomial system of nomenclature and the recognition of the species in general as a supposedly objective reality and the unit of classification. The form of Ray's specific definitions seems, however, to imply that the term "species" in Ray's mind was often more a "differentia," or specific adjective modifying the generic concept than a fully developed substantive name, and Ray did not apparently realize the convenience of applying the binomial method of nomenclature universally. Even Linnæus at first introduced the specific, "trivial," or common name, merely as a marginal index or symbol of the full specific phrase. Ray recognized the considerable variability of species, but believed also in their separate creation and fixity. He frequently adverts to the internal characters of animals; and his book shows, that even by his time a considerable number of observations on the soft parts of animals had already accumulated.

\section{The Linnean Epoch.}

The work of Ray in botany and zoölogy fully prepared the way for Linnæus, whose epoch may be characterized as the Legislative Epoch, because his methods of description and classification, and especially his nomenclature exerted such profound formative and regulative influence upon the work of his contemporaries and successors that he was called the "lawgiver of natural history."

\section{Linnaus's Broader Contributions to the Class Mammalia.}

One of the most enduring claims of Linnxus upon the grateful memory of posterity arises from his felicitous coinage of the word "mammalia" (animals with mammæ or breasts after analogy with Latin words like animal ") as a class name for the forms characterized by Ray as "viviparous hairy animals." Thus not only the terrestrial hairy oviparous quadrupeds,

1 Theodore Gill, l. $c$. 
but also the acuatic Vivipara now called Cetaceans and Sirenians, were for the first time definitely included under a single class name.

In attempting to appraise Linnæus's contributions to the broader knowledge of the chass of mammals, we must bear in mind what Dr. J. A. Allen has well shown," namely: that Linnæus was primarily a botanist, that his interest in mammals was incidental, that his opportunities for studying them were very limited, that his first-hand knowledge of extra-European manmals was practically nil, and finally that several of his ordinal groupings of mammals (e.g., rhinoceros with the rodents) now appear highly unnatural and even ludicrous.

On the other hind, there are certain considerations which may prevent us from thinking any the less of bis judgment and genius on that account. Although Linneus may have known very little about extra-European mammals, he had, nevertheless, a fairly good conception of the essential features of mammals as a class, as shown by his definition in the tenth edition of the "Systema Nature" (1758). Here in concise phrase he states that mammals have a heart with two auricles and two ventricles, with hot red blood; that the lungs breathe rhythmically; that the jaws are slung as in other vertebrates, but "covered," i. e., with fiesh, as opposed to the "naked" jaws of birds; that the penis is intromittent; that the females are viviparous, and secrete and give milk; that the means of perception are the tongue, nose, eyes, ears and the sense of touch; that the integument is provided with hairs, which are sparse in tropical and still fewer in aquatic mammals; that the body is supported on four feet, save in the aquatic forms, in which the hind limbs are said to be coalesced into a tail (the only erroneous idea in the whole definition).

Many of these characters had previously been noticed by Ray in his description of the hairy quadrupeds. It is not impossible, too, that Linnous may bave been assisted to the comprehension of the essential features of the mammals through his friendship with Bernard de Jussicu, who is said by Isidore Geoffroy Saint-Hilaire to have induced him to include the Cetareans in the class Mammalia; and possibly he also owed something to the researches of Klein and Brisson. In spite of all this, Linneus's own studies in medicine, in Holland, doubtless made him familiar with the anatomy of at least one mannmal, man; and on his journeys through the north of Europe he must have observed many other mammals at close range.

Thus was Linnaus prepared for the clear recognition and emphasis of another fact of far-reaching importance. It was evidently well known that the anatomy of the hairy quadrupeds was similar in plan, if not in detail, 
to that of man, and we find Descartes (for example, in his "Discourse on Method" Part V., 1637) advising those who wished to understand his theory of the action of the lungs and circulatory system, "to take the trouble of getting dissected in their presence the heart of some large animal possessed of lungs, for this is throughout sufficiently like the human" (ital, mihi). And it was further known that of all animals the, monkeys are most nearly like man, both externally and internally. This was asserted by Aristotle and other classical authors, but was fully demonstrated in a carefully prepared and illustrated work ${ }^{2}$ on the anatomy and appearance of animals from the Jardin du Roi, by a committee of savants of the French Academy, appointed by the Grand Monarch.

This work and these important observations may or may not have come under the notice of Linnæus on the occasion of his visit to Paris in 1738. At any rate, he did not hesitate to follow the logical consequences of these facts, namely, that in a strictly zoölogical classification, man would be grouped not only in the class Mammalia, but even in the same ordinal division with the monkeys. Accordingly, in the tenth edition of the Systema the earlier name Anthropomorphæ is replaced by Primates, and the genera Homo, Simia, Lemur and Vespertilio, are grouped under that order. The Primates were thus regarded as the chiefs of the hierarchy of terrestrial beings, and consequently, as in nearly all subsequent schemes down to the Darwinian Epoch, head the classified legions of creatures. Linnæus was too often at fault in surmising the generic and ordinal affinities of the species of the lower vertebrates; but this bold allocation of man to the order Primates surely bears the marks of genius, and led the way to the modern generalization that man is knit by ties of blood kinship to the Primates, and more remotely to the whole organic world.

Linncus's Principles in his Classification of the Mammalia.

The diagnostic definition given by Linnæus of the order Primates may be cited because it rests upon the principles and theories which guided him in classification and which led to his most successful groupings, as well as to his serious blunders. This definition is as follows:-

Inferior front teeth iv, parallel. laniariform [canine] teeth solitary [that is, in a single pair above and below].

Mammæ pectoral, one pair.

The anterior extremities are hands.

The arms are separated by clavicles, the gait usually on all fours ("incessu tetrapodo volgo").

They elimb trees and pluck the fruits thereof.

1 Memoires pour servir a l'histoire naturelle des animaux, a la Baye, 1716 (4to, 2 vols.), redigées par Perrault et Dodart. 
This definition was clearly insufficient to exclude all extraneous genera from this really natural order; for (1) under Lemur Linnasus included, not only all the then known forms now recognized as the suborder Lemuroidea, but also the "Flying Lemur," Galeopithecus, which properly either forms an order by itself with no near affinities with the Primates, or is at most a suborder of the Cheiroptera; (2) the definition also included "Vespertilio," $i$. e.; the bats, excepting $N$ octilio, an order more nearly related to the Insectivores than to the Primates.

Many of the characters selected by Linnueus for his ordinal diagnoses were of the "adaptive" or superficial kind, which are now known to have been most easily modifiable by changes in the external or internal environment. The reason for this mistake was, that Linnæxus regarded the mode of sustenance of a group as one of its most deep-seated attributes and most surely indicative of more or less hidden affinities with other groups. Iinnæus was constantly searching for natural groups, but he did not realize that the natural affinity of the members of the larger groups was due to descent from common ancestors, just as in the case of members of the same species. An example of his reliance upon sustenance is scen in his definition, in the tenth edition of the Systema, of the order Feræ, the Carnivora of later authors. Here "sustenance by rapine, upon carcasses ravenously snatched" is evidently felt to be connected with "front teeth in both jaws: supcrior vi, all acute," with "laniariform teeth [eanines] solitary," with "claws on the fect acute."

One of his dicta in botany was, that a character of great systematic importance in one group may be very variable in another; consequently he did not mention "sustenance" under Bruta, but contented himself with the two characters "front teeth none either above or below" and "gait awkward (incessus ineptior)." As this order included the elephant, the manatee, the sloth, the great ant-eater and the scaly ant-eater, it has been justly cited as a grossly unnatural assemblage, and the grouping accounted for by Linnxus's ignorance of the animals composing it.

Now it is possible that Linneus himself did not regard this assemblage as natural, but merely as a convenient artificial grouping. But I am more disposed to attribute its existence to his habit of searching for lidden alfinities helow the most obvious external differences, as when he plared the seals in the order Ferse, joined the bats with the Primates, the horse and the lippopotamus, the rhinoreros with the Rodents, and the pig with the Insertivores (in the ordor Bestim).

Linnmus recognized that the ordinal classification of the mammals was a difficult problem, as is shown by the conspicuous changes (not always improvements in our eyes) and redistributions which he made between the 
first and "tenth" editions of the Systema and further by the fact that Erxleben, who revised and extended the Systema (1777), abandoned the ordinal divisions entirely and merely listed the genera seriatim. The difficulty of the problem is indicated by the fact that Cuvier, with far better material and more extensive knowledge, was constantly deceived by "adaptive" (or homoplastic) resemblances. Even Cope, who wrote much on homoplastic and convergent evolution, was himself deceived by the similarities of structure in the marsupial "mole," Notoryctes, and the Cape golden mole, Chrysochloris, an undoubted insectivore.

The most "inexcusable" blunder of Linnæus, that of placing the rhinoceros with the Rodents under the order "Glires," may have been due, not to carelessness, but to the fact that the Indian rhinoceros has a single pair of close-set cutting incisors in the upper jaw, which oppose the elongate incisor-like appressed canines of the lower jaw and thus show a superficial approach to the rodent dentition. If Linnæus had known that Hyrax, which Pallas described as a Rodent ("Cavia"), had cheek-teeth like those of Rhinoceros, he doubtless might have felicitated himself upon his supposed astuteness.

In brief, Linnæus, as fully shown by Whewell, ${ }^{1}$ from his profound and wide botanical knowledge, was acquainted with many natural orders, and strove constantly to recognize uthers. He knew that a character of great diagnostic and fundamental value in one order may be of slight value in another; he knew that even in a natural order some of the diagnostic and fundamental characters might be absent in certain members otherwise clearly allied to a given series. He knew that a natural series is "natural" because of the totality of its characters, that the "genus makes the character," and not vice versa, a hard doctrine to many of his contemporaries. When Linnæus had arrived at a conception of any given natural order, he selected certain characters as diagnostic, but not necessarily universal, and constructed professedly artificial or only partly natural keys to his "natural" orders.

When Linnæus turned his attention to the classification of animals, we may believe that he followed the same principles. In this application of the principles gained in one subject to the data of another, we have a good example of the felicitous union of specifically distinct ideas to produce a line of ideas that are new and very fertile.

\section{The Relation of Linnøus to his Successors.}

Linnæus inherited from Ray and from the scholastic system the dogma of the separate creation and objective reality of species, which became 


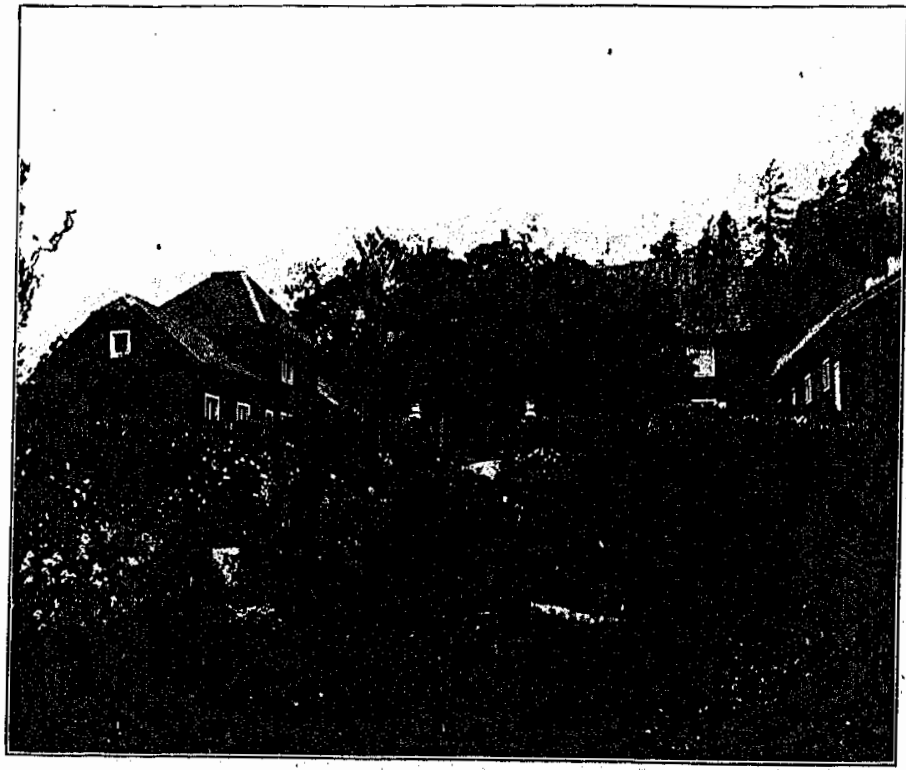

Courtesy N.Y. Botan. (iarlem.

W. A. Murrill, P'hoto.

FIG. I. HAMMARBY, THL: COINTRY HOML OF LINN FULS NEAR liPAALA SIWLEFN.

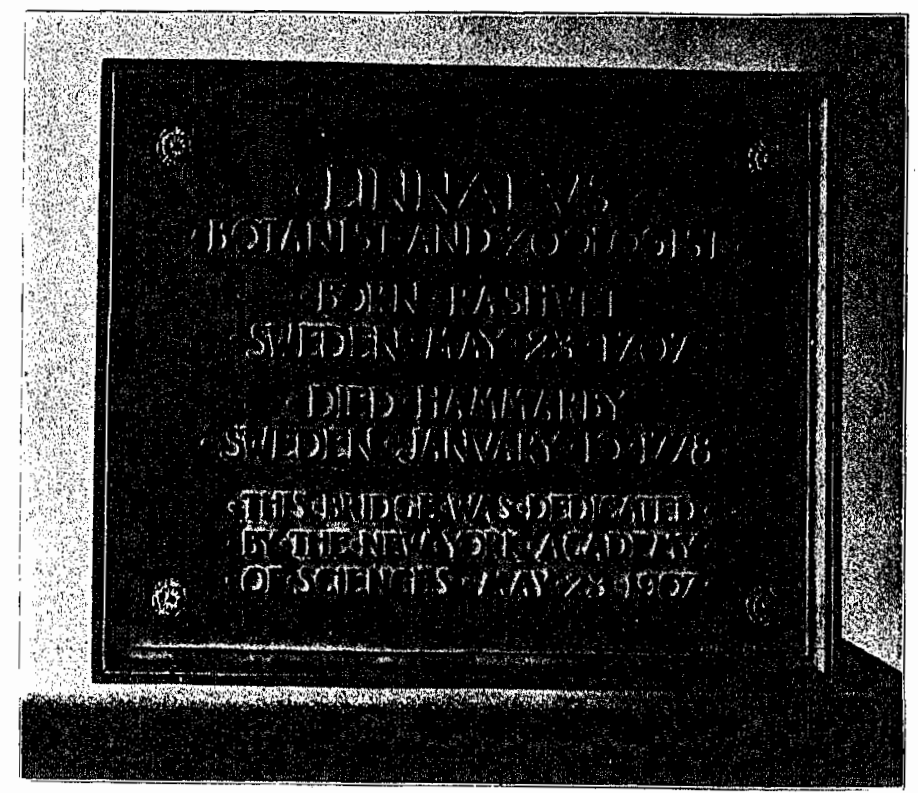

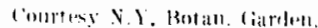

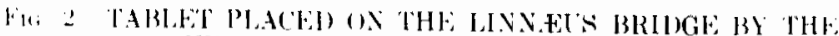

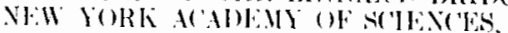


developed and strengthened in his hands as a result of his observations. His dictum was species tot sunt diverse quot diversce forma ab initio sunt create. The resemblances between members of a single species were hence held to be due to descent from an original pair, and the mutual infertility of different species to be the natural penalty of the effort to traverse the gaps established from the beginning.

This view was somewhat modified in later editions of the Systema, in which linneus beld that "all the speries of one genus constituted at first (that is at the Creation) one species, ab intio unam constituerint speriem; they were subsequently multiplied by hybrid generation that is by intercrossing with other species." 1

The general relation of Jinnaus to his succesisors may be summarized in a few words. The sixth epoch in the history of zoology extends from the latter pait of the eighteenth to the middle of the nincteenth century, and may be called the Anatomical Epoch, because, through the labors of (uvier and his great English pupil and sucessor, Richard Owen, the taxonomic studies of the Linnean sehool were suppleruented by the establishment and great development of the sciences of comparative anatomy and paleontolong. In spite, however, of the improvement and expansion of (dassification, its bearing upon evolution was not gemerally pereived. Curier's researches in these seiences further extended the dogma of the fixity of spereies; but Owen, through his broader knowledge, gradually gave up the idea and became an evolutionist, alt bough not al selectionist.

The seventh epoch, the Darwinian, in which happily we are living. lias seen the overthrow of the traditional doet rine of the fivity of species, and hat initiated the re-examination of all morpholegieal pheromena in the light of the doctrince of evolution. These morpholocical facts are refterted nimere and more in our evolving classitications, which are the outgreweth of the Linnean system, and which now aim to expreses, not only degrens of hereno-

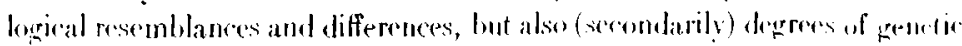
kinship.

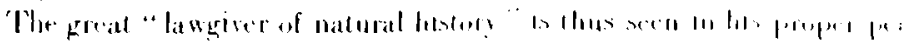

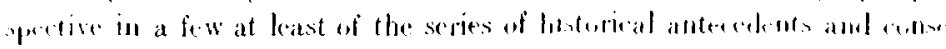

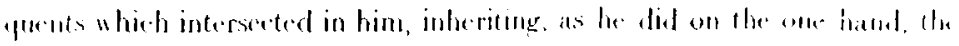

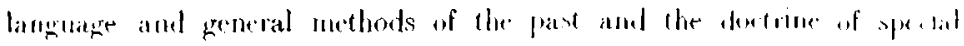

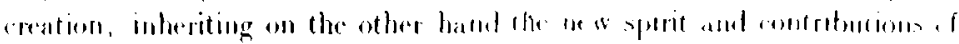

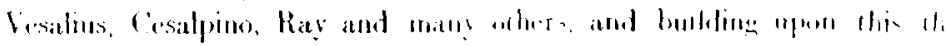

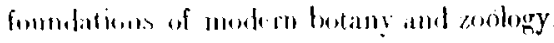


At the close of the reading of Dr. Allen's address, recess was taken till two o'clock, p.m. During this time the Council entertained at luncheon at the Hermitage Hotel, near Bronx Park, the delegates of sister societies and invited guests. Afterward the special exhibits at the Botanical Museum were examined, and then was delivered the following address.

\section{LINNAEUS AND AMERICAN BOTANY.}

By Per Axel Rydberg, Ph. D.

\section{Mr. Chairman, Ladies and Gentlemen:}

I have been asked to make a short address to you on Linnærus and his relation to North American botany. That the selection fell on me was not because I was the most able one to deliver such an address, for there are

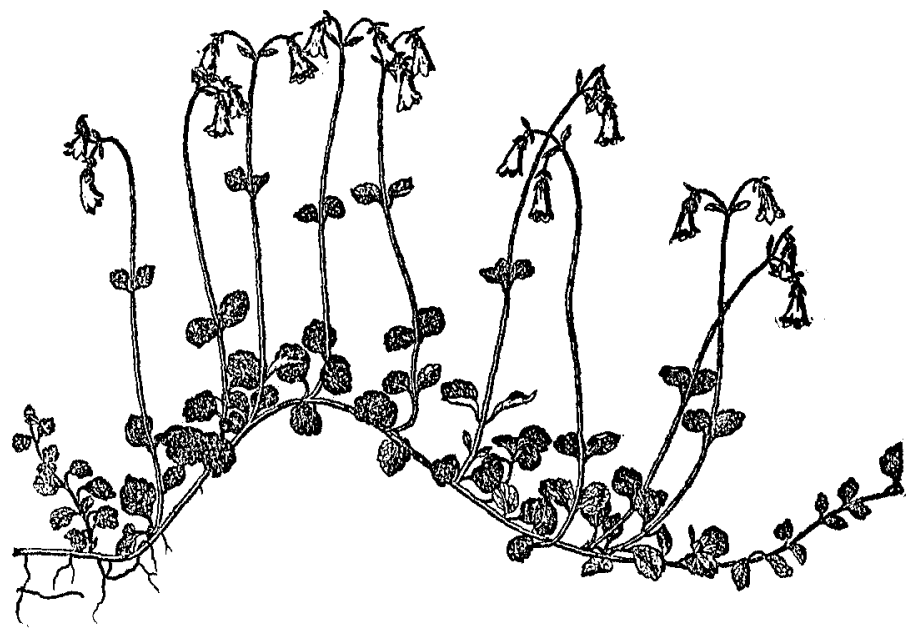

THE TWIN-FLOWER, LINNAA BOREALIS

A plant especially beloved by Linnæus, and dedicated to him by Gronovius.

many abler men present, but simply because I was born in the same country as Linnæus. In fact, my grandfather came from the same province of Smaland and even from a parish adjoining that of Stembrohult, in which my illustrious countryman was born.

In the early part of the seventeenth century there lived in Jonsboda, 